DOI: https://doi.org/10.24867/04DS02Ninkov

\title{
УТИЦАЈ ЕЛЕКТРОНСКОГ СИСТЕМА НАПЛАТЕ НА ДИНАМИЧКЕ ЕЛЕМЕНТЕ ЛИНИЈЕ
}

\section{THE INFLUENCE OF AN ELECTRONIC PAYMENT SYSTEM ON DYNAMIC ELEMENTS OF LINE}

\section{Слободан Нинков, Павле Питка, Факултет техничких наука, Нови Сад}

\section{Област - САОБРАһАJ}

Кратак садржај - У овом раду је извршена процена уштеде времена укриявањ а путника у возило и утицај на динамичке елементе линија за случај замене класичног система наплате карата електронским системом у јавном градском превозу путника у Новом Саду.

Кључне речи: Систем наплате, измена путника, јавни превоз путника

Abstract - This paper evaluates reduction in boarding time of passenger and influance on dinamic elements of line for the requirements of substituting the classical ticketing system with the electronic one in public passenger transport Novi Sad.

Keywords: Payment system, passenger substitution, public passenger transport

\section{1. УВОД}

У систему ЈГПП-а у Новом Саду се тренутно користи класичан систем наплате. Класичан систем наплате (КСН) и поред великог броја позитивних страна представља застарелу технологију која је у већини развијених европских градова замењена електронским системима наплате (ЕСH).

Тренутни систем наплате у Новом Саду не пружа довољну информациону основу помоћу које би управљање системом било ефикасно. Поред тога што тренутни систем наплате утиче на ефикасност менаџмента, он такође утиче на брзину измене путника. Измена путника се реализује на стајалиштима док се возило налази у стању мировања. Бржи системи наплате омогућавају краће задржавање возила на стајалиштима самим тим скраћују време обрта возила. Смањењем времена обрта у постојећем систему ЈГППа у Новом Саду би могло имати значајан утицај и на остале динамичке елементе линија.

На територији Новог Сада дневно се оствари и до 180 000 вожњи путника [1], што представља значајан потенцијал за оптимизацију времена задржавања возила на стајалишту.

\section{NAPOMENA:}

Овај рад проистекао је из мастер рада чији ментор је био др Павле Питка, доцент.
Предмет овог рада је да се установи време задржавања возила на стајалиштима ради измене путника и да ли се и у којој мери може утицати на смањење тог времена кроз имплементацију електронског система наплате. Циљ рада је да се покаже како смањење времена задржавања возила на стајалишту може утицати на динамичке елементе линија.

\section{2. МЕТОДОЛОГИЈА ИСТРАЖИВАЊА}

Утврђивање просечног времена потребног за улазак путника у возило је извршено у систему ЈГПП-а у Новом Саду. Истраживање је спроведено на појединим стајалиштима система, која имају велику фреквенцију возила. Стајалишта на којима је вршено истраживање: Булевар Ослобођења - Лутрија Војводине; Булевар Михајла Пупина - РК "Базар“; Стражиловска улица Факултети. Истраживање је извршено, у понедељак 16.07.2018. године, у периодима од по 2 сата на сваком од наведених стајалишта.

Истраживање је обухватило мерење времена задржавања возила на стајалишту, као и бројање путника који су ушли у возило. Истраживање је вршено мануелно помоћу истраживача - бројача. За мерење времена коришћен је мобилни телефон са инсталираном апликацијом Stopwatch, док је бројање путника који су ушли у возило вршено мануелно.

\section{3. РЕЗУЛТАТИ ИСТРАЖИВАҢА}

Истраживање на градским линијама је обухватило 81 измену путника, односно 386 улазака путника у возило. Резултати истраживања су представљени графички на слици 1. На основу резултата истраживања је добијено да просечно време уласка једног путника у возило на градским линијама износи 6,17 секунди, уз просечну стандардну девијацију од 3,28.

Линије које су обухваћене овим истраживањем су: Линија 1, Линија 3, Линија 4, Линија 6, Линија 8 , Линија 9, Линија 11А і Линија 12. Резултати истраживања по обухваћеним линијама су дати на слици 2.

Као што се може приметити време од 6.17 секунди по путнику представља неприхватљиву величину гледано са аспекта модерног јавног превоза европских земаља. Потребно је тежити његовом смањењу, поготово у подручјима где влада повећани интензитет захтева за превозом. 


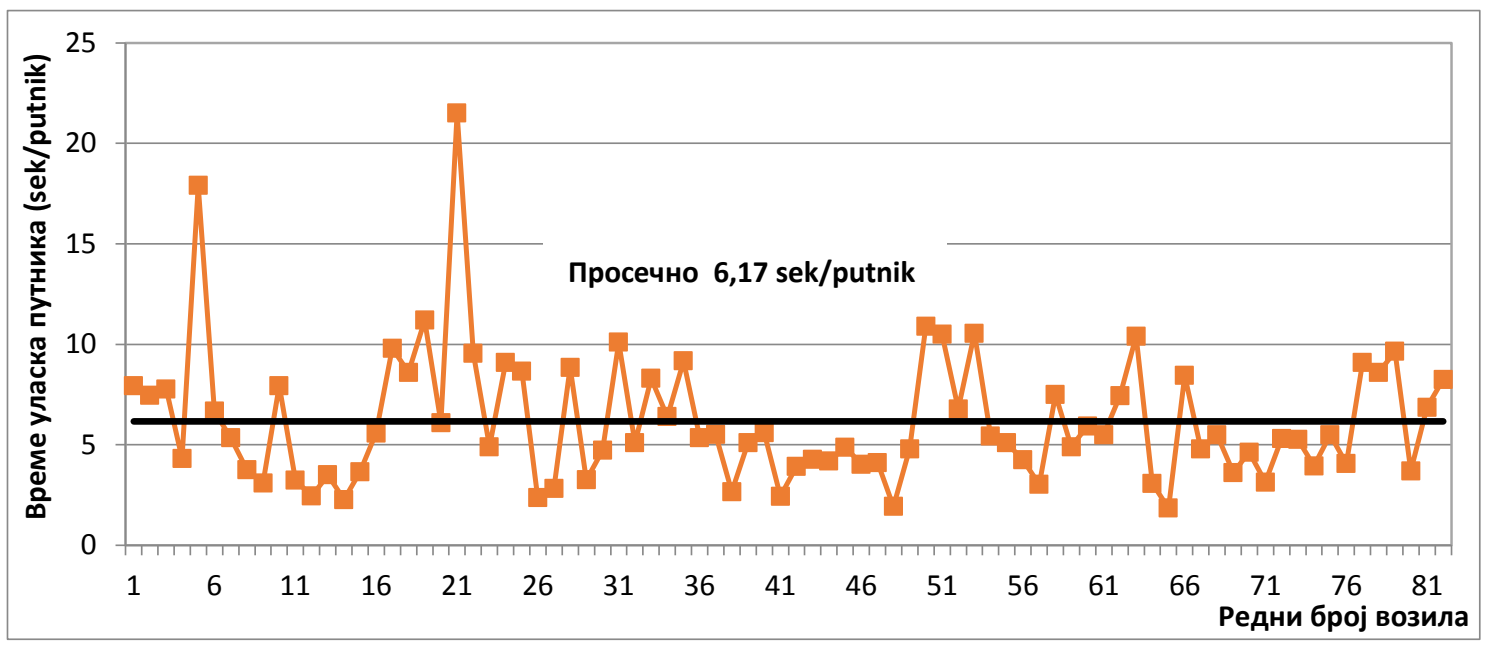

Слика 1. Резултати истраживања

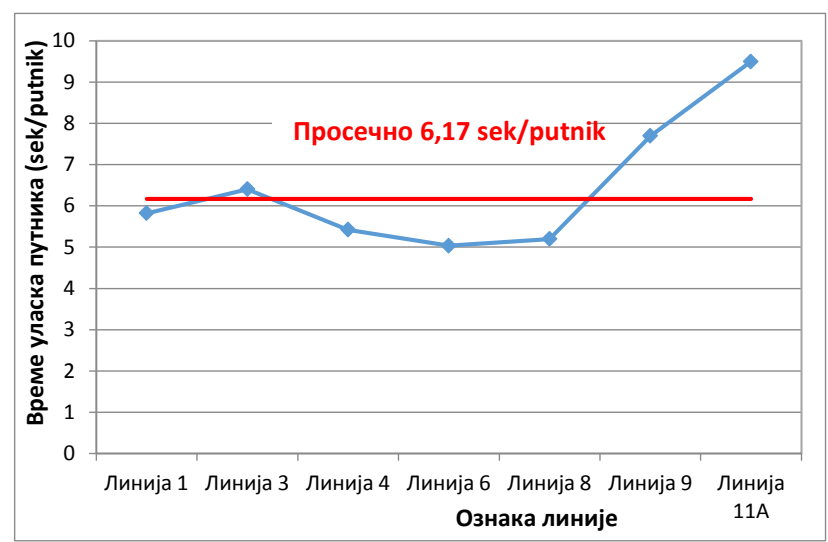

Слика 2. Резултати истраживаға по линијама

Међутим ако се узме у обзир да у литератури за систем наплате код возача просечно време уласка износи 11 секунди по путнику, онда резултати добијени приликом истраживања у Новом Саду нису лоши. Већа брзина уласка путника постиже се захваљујући великим уделом месечне (показне карте) у структури карата.

\section{4. ЕЛЕКТРОНСКИ СИСТЕМ НАПЛАТЕ}

Полазећи од тога да је субјект наплате путник, може ce направити основна класификација према којој постоје три система наплате [2]: Систем наплате преко кондуктера; Систем наплате преко возача; Систем наплате самоуслуживањем.

Електронски систем наплате (ЕСН) спада у систем наплате самоуслуживањем што значајно убрзава измену путника на стајалиштима (Табела 1).

На тржишту постоје три врсте безконтактних картица. Подела картица је извршена према растојању које је потребно да би се извршила размена података: веома кратког домета; кратког домета; већег домета.

Табела 1. Време уласка путника у зависности од система наплате [3]

\begin{tabular}{|l|c|}
\hline \multicolumn{1}{|c|}{ Куповина карте } & $\begin{array}{c}\text { Време уласка путника } \\
\text { (секунди/путнику) }\end{array}$ \\
\hline У возилу - кеш & 11.06 \\
\hline У возилу - магнетна трака & 3.78 \\
\hline У возилу - безконтактна картица & 2.93 \\
\hline Ван возила (1 врата) & 2.35 \\
\hline Ван возила (2 врата) & 1.74 \\
\hline Ван возила (3 врата) & 1.32 \\
\hline
\end{tabular}

Безконтактне картице веома кратког домета се морају поставити на површину читача. Иако изгледа да је ипак потребан контакт, чињеница је да у контактне картице спадају оне које се морају уметнути у читач.

Картице кратког домета су најчешће присутне у пракси. Растојање потребно да се очитавање оствари је до 10 $\mathrm{cm}$. Размена података се остварује за 0,1 - 0,3 sek.

Картице које могу бити очитане и на растојању до $1 \mathrm{~m}$ су картице већег домета. Оне имају највећу практичност, јер не доприносе стварању застоја приликом валидације.

Безконтактне картице функционишу помоћу RFID технологије (Radio Frequency Identification) која помоћу високе фреквенције омогућава пренос података без потребе за контактом металних делова.

\section{5. ДИНАМИЧКИ ЕЛЕМЕНТИ ПРЕ И ПОСЛЕ УВОЪЕЊА ЕСН}

Динамички елементи линије се утврђују редом вожње који се мења периодично, у складу са променама превозних захтева на линији. Динамички елементи истовремено представљају и значајне параметре квалитета ЈГПП-а [4].

Динамички елементи линија су:

Број возила на линији,

Време обрта,

Брзина обрта,

Интервал слеђења возила на линији,

Фреквенција,

Превозна способност линије.

Образац који нам приказује зависност између времена обрта, интервала слеђења и броја возила на линији:

$$
\mathrm{i}=\frac{\mathrm{T}_{\mathrm{o}}}{\mathrm{N}_{\mathrm{r}}}
$$

Где је:

i - Интервал слеђења [min],

$\mathrm{T}_{\mathrm{o}}$ - Време обрта [min],

$\mathrm{N}_{\mathrm{r}}$ - Број возила на линији [возила].

Смањењем времена измене путника скраћује се време обрта, што може даље да утиче на интервал слеђења и број возила на раду и ту разликујемо три случаја. 
Први случај је да је смањење времена обрта мање од интервала слеђења и тада се задржава исти број возила на линији, а интервал слеђења се смањује. Тада се са постојећим ресурсима у систему добија бољи квалитет услуге, јер смањени интервал слеђења возила значи бољу временску приступачност путницима и већу превозну способност. Повећање превозне способности позитивно утиче на комфор.

Други случај се јавља када су уштеде у времену обрта веће или једнаке пројектованом интервалу слеђења. Тада је могуће смањити број возила и задржати постојећи пројектовани интервал, односно могуће је направити уштеде у систему ЈГПП-а, а задржати претходни квалитет услуге (интервал слеђења, превозна способност и комфор остају непромењени).

Код трећег случаја, баш као и код другог уштеде у времену обрта су веће или једнаке пројектованом интервалу слеђења, али се не смањује број возила на раду већ се као код првог случаја смањује интервал слеђења и са постојећим ресурсима значајно повећава квалитет услуге. У овом раду као опција за оптимизацију система биће разматран само први или други случај.

На слици 3 се могу видети времена обрта у оба случаја: Класичан систем наплате и електронски систем наплате.

ЕСН омогућава да се време обрта смањи на свакој линији без изузетака.

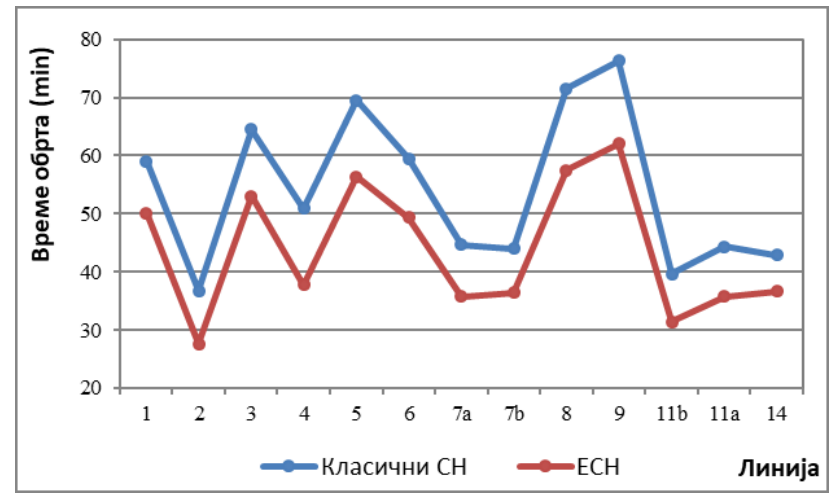

Слика 3. Времена обрта за КСН и ЕСН

На линијама 8 и 9 су остварене највеће уштеде у временима обрта. На линији 8 је након симулације установљена уштеда од 14 минута, док је на линији број 9 остварена уштеда од 14,3 минута.

На те две линије актуелне вредности интервала слеђења износе 8,5 и 10,3 минута респективно, што даље значи да је могуће смањење броја возила на раду за једну јединицу.

Имплементација система електронске наплате ће имати позитиван утицај на превозну брзину кроз смањење временских губитака која су актуелна на стајалиштима. На слици 4 је дата превозна брзина по линијама за случај постојећег стања и унапређеног система наплате.

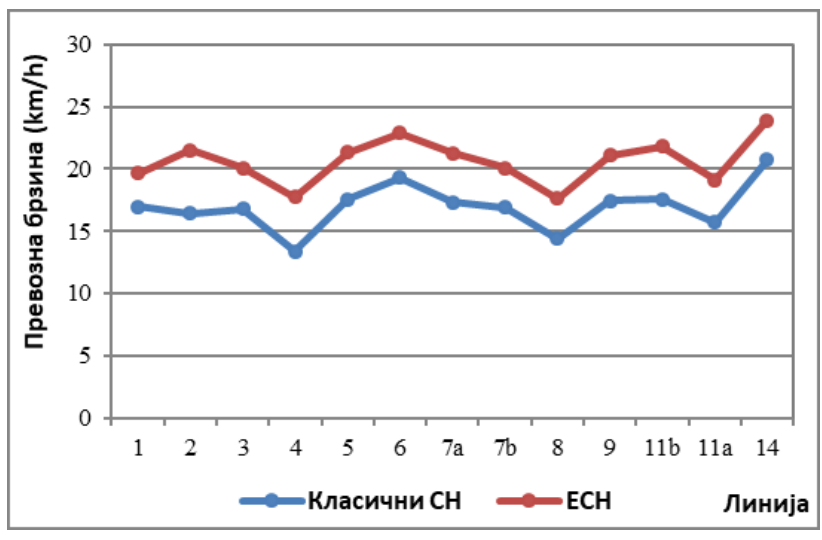

Слика 4. Превозна брзина по линијама у вршном сату

На претходној слици се види да је повећање превозне брзине значајно на свакој линији и на нивоу целокупног система за анализирани вршни час износи просечно $3,7 \mathrm{~km} / \mathrm{h}$. Највеће вредности које су израчунате односе се на линију број 2 и линију број 4 и износе 5,1 и 4,4 km/h. Повећање брзине превоза директно зависи од броја превезених путника и дужине линије. Највећи ефекти на повећање брзине улед бржег система наплате је на линијама са мањим дужинама трасе, а са већом изменом путника.

Када уштеде у времену нису веће од просечног интервала слеђења, тада не постоји могућност смањења броја возила на раду, јер би у супротном интервал слеђења био повећан што би директно утицало на смањење квалитета услуге. Тада се позитивни ефекти могу наћи у повећању квалитета услуге кроз смањење вредности интервала слеђења, односно повећање фреквенције возила на посматраној линији.

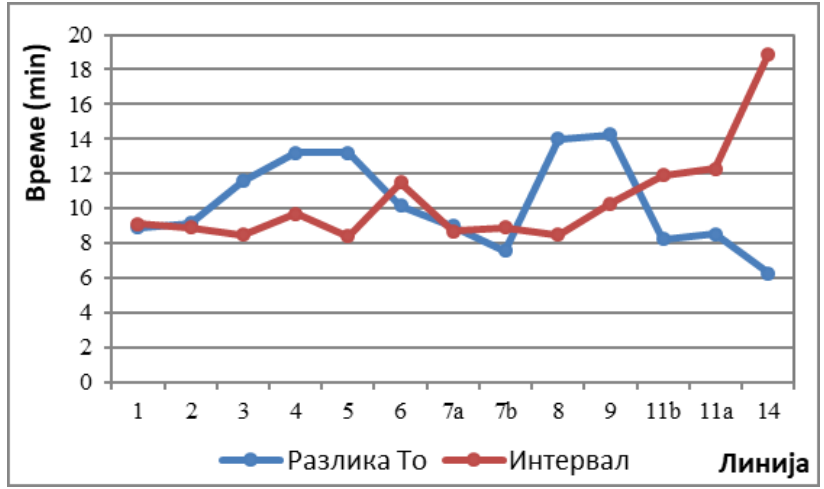

Слика 5. Однос уштеде у времену обрта и интервала

На слици 5 може се уочити да се од 13 посматраних линија на 8 може приметити уштеда у времену већа од интервала слеђења што омогућава смањење броја возила на раду за једну јединицу. На 5 посматраних линија $(6,7 \mathrm{~b}, 11 \mathrm{~b}, 11 \mathrm{a}$ и 14) уштеда у времену је мања од вредности интервала слеђења и могућност за смањење броја возила на раду не постоји. На тих 5 линија ипак постоји могућност смањења интервала слеђења, односно повећања фреквенције возила без увођења додатних возила на линији. 


\section{6. ЗАКЉУЧАК}

Имплементацијом ЕСН пре свега информациони систем јавног превоза бива значајно унапређен. Међутим, увођењем електронског система наплате смањује се просечно време уласка путника у возило. Смањењем задржавања возила на стајалишту смањује се време обрта, што може имати позитиван утицај на друге динамичке елементе линија. Пре свега, долази до повећања превозне брзине. Превозна брзина представља просечну брзину коју путник остварује приликом кретања између два терминала.

У оквиру овог рада извршено је истраживање потребног времена уласка путника у возило ЈГПП-а у Новом Саду, где је у примени класичан систем наплате без кондуктера у возилу. Истраживање је извршено на стајалиштима ЈГПП-а, при чему је за просечно време уласка путника у возило добијено 6,17 секунди.

Прегледом доступне литературе дошло се до закључка да увођењем електронског система наплате (бесконтактне смарт картице) у систем ЈГПП-а у Новом Саду просечно време уласка путника у возило ЈГПП-а може да се смањи на 2,93 секунде.

За познате расподеле улазака путника у возило (систематско бројање путника 2010. год) и претпостављене уштеде времена при уласку путника у возило (последица примене ЕСН) извршена је симулација времена обрта возила на линији. На основу нових (смањених) времена обрта израчунати су и други динамички елеменати на свим градским линијама, уз претпоставку да је време задржавања возила на стајалишту детерминисано временом уласка путника у возило.

Добијени резултати су показали да увођењем ЕСН уз задржавање истог броја возила на раду интервал слеђења може да се смањи у распону од 1 минута до 14,3 минута у зависности од линије и периода у току дана. Док је број возила на раду могуће смањити за 1 возило на линијама $2,3,4,5,7 \mathrm{a}, 8$, и 9.

Из наведеног истраживања и извршене симулације може се закључити да се увођењем ЕСН у систему ЈГПП-а у Новом Саду могу постићи значајна побољшања квалитета услуге.

\section{7. ЛИТЕРАТУРА}

[1] Системско-генерално бројање и анкета путника у јавном градском и приградском превозу путника на подручју Новог Сада, ЈП "Урбанизам" завод за урбанизам, Нови Сад, 2010.

[2] П. Гладовић, В. Поповић, М. Симеуновић, „Информациони системи у друмском транспорту“, Нови Сад, ФТН Издаваштво, 2014.

[3] Tirachini, Alejandro, i David A. Hensher, „Bus congestion, optimal infrastructure investment and the choice of a fare collection system in dedicated bus corridors". Transportation Research Part B: Methodological 45 (5), 2011, Elsevier Ltd: 828-44. doi:10.1016/j.trb.2011.02.006.

[4] Р. Банковић, „Организаиија и технологија јавног градског путничког превоза“", Београд, Саобраћајни факултет, 1994.

\section{Кратка биографија:}

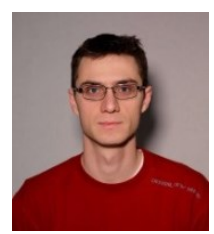

Слободан Нинков рођен у Сомбору 1991. год. Bachelor рад на Факултету техничких наука из области Експертизе саобраћајних незгода - Временско-просторна анализа саобраћајних незгода са учешћем пешака одбранио је 2016. год

контакт: ninkov91@gmail.com

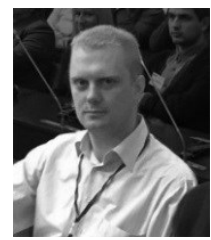

Павле Питка рођен је у Шашинцима 1983. Докторирао је на Факултету техничких наука 2016. год., а од 2017. је звању доцент. Област интересовања су системи јавног превоза. 